\title{
An Empirical Study on Population Capacity of Urban Land in Macao
}

\author{
En Chen \\ Jingwei Guangdong, Hong Kong and Macao Economic Research Center \\ Jinan University \\ Guangdong, China
}

\author{
Guaili Zhang* \\ Nangfang College \\ Sun Yat-sen University \\ Guangdong, China \\ *Corresponding author
}

\author{
Tao $\mathrm{Fu}$ \\ Nangfang College \\ Sun Yat-sen University \\ Guangdong, China
}

\begin{abstract}
Macao is undergoing rapid economic development, but its land space is narrow and population density is high, the overload state of Macao's urban land and population are the outstanding problems, which are urgently faced and dealt with for Macao's economic and social development. This paper firstly analyzes the increasingly prominent contradiction between supply and demand situation of Macao's land and population in theory. Then this paper assesses and predicts Macao's economic development in the next decade, the prospect of intensified conflicts between population growth and land supply and demand. Furtherly, the author builds an index system of land bearing capacity and econometric models for empirical analysis overload conditions of the population of Macao's urban land, and finally puts forward some relevant conclusions and recommendations.
\end{abstract}

Keywords-Macao; urban land's population; demand and supply contradiction; bearing capacity

\section{INTRODUCTION}

As an international gambling tourism center and a famous micro economy in Asia-pacific region, Macao's economy have had a great leap-forward development since its sovereignty being transferred back to China. At the same time, its population has grown rapidly and the contradiction of supply and demand of land has been intensified. Macao boasts an area of only 29.7 square $\mathrm{km}$, but has a population of 5,60,100 and an economic aggregate amounting to 226,263 billion Macao dollars (in 2010). Despite the present limited land resources and large population, the future economic growth sees a great potentiality and population growth a great inertia. The population and economic growth in Macao will contradict even more seriously with the narrow urban land in the future. Therefore, this paper will first conduct an in-depth analysis of Macao's population carrying capacity of land, and then make an objective

This is the 2013 annual Guangdong to build "theory of the PLA," funded project (project approval No: LLYJ1319) and the College of Humanities and Social Sciences in Guangdong Province major research project (project approval No: 10ZGXM79001) funded projects. evaluation and prediction of the contradiction among land supply, population growth and industrial development in the next decade. Based on these analyses, an index system of land, population and economy carrying capacity will be constructed, and empirical analysis of population carrying capacity of the urban land will also be made. This paper will finally propose the measures to optimize the land use structure, the strategy of expanding the land use scale through regional cooperation, and the ways to improve the population carrying efficiency of land. This study is believed to be both theoretically and pragmatically significant for Macao to maintain its economic prosperity in the long run and promote its economic diversification effectively.

\section{A THEORETICAL ANALYSIS ON POPULATION CAPACITY IN MACAO}

\section{A. Contradiction between Supply and Demand of Land Is Sharp}

Macao boasted a very small land area in the past Through sea reclamation for nearly 100 years, the land area was expanded to 29.7 square $\mathrm{km}$ in 2010 , which is equal to about 1/37 of Hong Kong and about 1/67 of Shenzhen. It is a famous micro economy in the Asia-pacific region. With so small an area, it can bear a very limited capacity for population and economy. Furthermore, the fact that a large part of the land is in the form of platform and hills restricts the land planning and land use. Over the years, Macao has been applying a diversified land institution, which hinders the marketing of land and thereby hinders the allocation of land for production and residential ends. This land institution further decreases the carrying capacity of land for the need of economy and society. Macao's GDP is only 1/6 as much as the city of Shenzhen. However, the GDP produced by every square $\mathrm{km}$ in Macao is 12 times of that in Shenzhen and the population is 42 times. Macao boasts so small a land area, while it is supporting so many population and economic activities. 


\section{B. Expanding Land by Sea Reclamation}

In 1840, the land in Macao was still in the form of original ecology. It boasted a land area of only 4.76 square $\mathrm{km}$, including 2.78 square $\mathrm{km}$ of Peninsula and 1.98 square $\mathrm{km}$ of Taipa and Coloane. It was a small island of hills, with a very small land area. To expand the industrial and residential land, Macao launched several large-scale sea reclamations, which extended the southeast coast line outward for about $1 \mathrm{~km}$. The coast line of the Areia Preta on the northeast and the Closing Road on the north was also extended outward for about 500 to 600 meters. Besides, the northeast, northwest and south central of Taipa are all new coasts made by sea reclamation. There are also two large areas of reclamation in Shek Pai Wan, which is on the northwest of Coloane Island, and Deepwater Harbor, which is on the northeast. Through 10 decades of sea reclamation, Macao's land area reached to $29.7 \mathrm{~km}$ in 2010, including 9.3 square $\mathrm{km}$ of Macau Peninsula, 6.8 square $\mathrm{km}$ of Taipa, 7.6 square $\mathrm{km}$ of Coloane, and 6.0 square $\mathrm{km}$ of Cotai Reclamation. Within 30 square km of current Macao's land, about 25 square $\mathrm{km}$, which is about 5 times of the original land area, are developed by sea reclamation. Sea reclamation is so far a major way of expanding land in Macao.

Macao has gained many flat and fine urban lands through sea reclamation. Those lands have greatly relieved the shortage of land in Macao and provided more rooms for the development of economy and society. However, we find that sea reclamation has damaged the ecological environment. And many hydrological, geological, ecological and geomorphologic conditions have also been changed. Until now, most of the ecological coast lines in Macao have disappeared and the Geological structure has also undergone some changes. Those changes have weakened the abilities of land to protect itself from the changes of marine environment, while gradually strengthened the heat island effect. Meanwhile, the fact that most of the coast line has been extended to the deep sea area through 10 decades sea reclamation increases the cost of further reclamation while decreases the potentialities of further reclamation. Therefore, it seems unrealistic for Macao to expand its land area on a large scale through the traditional way of sea reclamation in the future. The shortage of land will become a challenge for Macao's sustained and stable economic growth.

\section{Population Growth}

With a very small land area but a large population, Macao is so densely populated that there is 18,300 residents every square $\mathrm{km}$. Shenzhen is the most densely populated immigrant city in Chinese mainland. "Table I" But even compared with Shenzhen, the GDP carried by every square $\mathrm{km}$ in Macao, where is 5.74 billion Macao dollars, is 12 times of that in Shenzhen, where is 481 million Macao dollars. The population carried by every square $\mathrm{km}$ in Macao, where there are 18,400 people, is 42 times of that in Shenzhen, where there are 450 people. And it is 130 times of that in the Chinese mainland, which is so-called the most densely populated country in the world. And it is 361 times of the world population density. Macao ranks on the top of the world population density list. In addition, the population increases very fast in Macao. It increases from 425,000 people in 1998 to 560,100 people in 2009, with an annual growth rate of $2.23 \%$, which is 3 times of $0.64 \%$ in mainland China. With this trend, the land in Macao, which has already born too much, will carry much more pressure in the future.

TABLE I. COMPARISON WITH POPULATION DENSITIES BETWEEN MACAO AND MAINLAND CHINA

\begin{tabular}{|c|c|c|c|c|c|c|}
\hline & \multicolumn{3}{|c|}{ Macao } & \multicolumn{3}{|c|}{ Mainland China } \\
\hline Year & $\begin{array}{c}\text { Population } \\
\text { density(thousand } \\
\text { people/square } \mathrm{km} \text { ) }\end{array}$ & $\begin{array}{l}\text { Total population in the end of } \\
\text { the year(thousand people) }\end{array}$ & $\begin{array}{l}\text { Growth } \\
\text { rate(\%) }\end{array}$ & $\begin{array}{c}\text { Population } \\
\text { density(thousand } \\
\text { people/square } \mathrm{km} \text { ) }\end{array}$ & $\begin{array}{l}\text { Total population in the end of } \\
\text { the year(thousand people) }\end{array}$ & $\begin{array}{l}\text { Growth } \\
\text { rate }(\%)\end{array}$ \\
\hline 1998 & 18.01695 & 425.2 & 0.7583 & 0.129959 & 124761 & 0.9181 \\
\hline 1999 & 18.05042 & 429.6 & 1.0348 & 0.131027 & 125786 & 0.8216 \\
\hline 2000 & 16.98819 & 431.5 & 0.4423 & 0.132024 & 126743 & 0.7608 \\
\hline 2001 & 16.92636 & 436.7 & 1.2051 & 0.132945 & 127627 & 0.6975 \\
\hline 2002 & 16.47761 & 441.6 & 1.1221 & 0.133805 & 128453 & 0.6472 \\
\hline 2003 & 16.36264 & 446.7 & 1.1549 & 0.134611 & 129227 & 0.6026 \\
\hline 2004 & 16.82182 & 462.6 & 3.5594 & 0.135404 & 129988 & 0.5889 \\
\hline 2005 & 17.17376 & 484.3 & 4.6909 & 0.136204 & 130756 & 0.5908 \\
\hline 2006 & 17.95105 & 513.4 & 6.0087 & 0.136925 & 131448 & 0.529 \\
\hline 2007 & 18.42808 & 538.1 & 4.8111 & 0.137634 & 132129 & 0.5181 \\
\hline 2008 & 18.80822 & 549.2 & 2.0628 & 0.138335 & 132802 & 0.5094 \\
\hline 2009 & 18.37966 & 542.2 & -1.275 & 0.139035 & 133474 & 0.5060 \\
\hline 2010 & 18.3201 & 560.10 & 3.301 & 0.139035 & 133474 & 0.5060 \\
\hline Average & 17.53206 & 475.0917 & 2.1313 & 0.134826 & 129432.8 & 0.6408 \\
\hline
\end{tabular}

a. Note: This data is excerpted from China Statistical Yearbook and Statistics and Census Service, Government of Macao Special administrative Region.

\section{Imbalanced Structure of Land}

The land use structure in Macao is imbalanced. Macau Peninsula is the earliest area developed in Macao. Though its land area only takes up 33\% of the whole Macao, the major government administration, transportation, economy and cultural activity all take place there. Therefore, $90 \%$ of residents, social organizations and business organizations gather there. However, the island of Taipa and Coloane are rarely utilized due to their undeveloped transportation and infrastructure. It shows that the land use in Macao is severely uneven from area to area. "Table II" is an overview of the land use structure in Macao, from which we could find that there is only 0.2 square $\mathrm{km}$ of commercial land, accounting for $0.67 \%$ of the total area. 
TABLE II. The LAND Use StRUCtURE IN MACAO

\begin{tabular}{|l|l|l|l|l|}
\hline \multicolumn{5}{|c|}{ Estimated land area(km2) } \\
\hline Land use type & 2008 & 2009 & 2010 & 2011 (First quarter) \\
\hline Commercial and residential land & 2.7 & 2.7 & 2.7 & 2.7 \\
\hline Commercial land & 0.2 & 0.2 & 0.2 & 0.2 \\
\hline Industrial land & 0.9 & 0.9 & 0.9 & 0.9 \\
\hline Others & 21.4 & 21.6 & 21.8 & 21.9 \\
\hline Road & 4 & 4.1 & 4.1 & 4.1 \\
\hline Total & 29.2 & 29.5 & 29.7 & 29.8 \\
\hline
\end{tabular}

b. Note: This data is excerpted from Macao Cartography and Cadastre Bureau.

From the viewpoint of industry structure, which is service-oriented in Macao, there is a serious shortage of commercial land in Macao. Besides, there is only $0.9 \mathrm{~km} 2$ of industrial land, which are mainly distributed in the west and northeast of Macau Peninsula, mixing with the residential area and commercial area. There is $2.7 \mathrm{~km} 2$ of commercial and residential land in Macao, which could be divided into senior residential area and civilian residential area. The civilian residential area is small but densely populated, equipped with poor infrastructure and living condition. Until 2009 , there is only $3.8 \mathrm{~km} 2$ of production and residential land in Macao, which is $12.75 \%$ of total land area. It could be concluded that the production and residential land in Macao is severely inadequate.

\section{E. Conflicts between Service Industry and Industrial Development}

With rarely any agriculture, the industry structure in Macao is made up of secondary industry and tertiary industry.
The secondary industry, which includes water, electricity, coal gas, manufacturing, operating and construction according to the industrial classification in Macao, takes up $10 \%$ of GDP. While the tertiary industry takes up $90 \%$ of GDP. Taking 2010 as an example, the service industry takes up $89.14 \%$ of GDP. The tertiary industry occupies an absolutely dominant position in the economic structure of Macao, and therefore occupies most of the land. The service industry in Macao is not developed on the basis of the first industry and secondary industry, but relies on the gabling industry, which is of short industry chain and weak industrial effect. Its foundation is very weak. The gaming industry, whose total revenue accounts for $80 \%$ of the whole industry, is the major part of service industry. Due to the specialty of the gambling industry and the development of microeconomy, the industrial structure in Macao should be appropriately diversified. "Table III"

TABLE III. INDUSTRIAL STRUCTURE OF MACAO UNIT: \%

\begin{tabular}{|l|l|l|l|}
\hline \multicolumn{1}{|c|}{ Year } & Proportion of secondary industry & Proportion of tertiary industry & \multicolumn{1}{c|}{ Total } \\
\hline 2004 & 12.78 & 87.22 & 100 \\
\hline 2005 & 12.05 & 87.95 & 100 \\
\hline 2006 & 15.17 & 84.83 & 100 \\
\hline 2007 & 19.75 & 80.25 & 100 \\
\hline 2008 & 19.13 & 80.87 & 100 \\
\hline 2009 & 17.21 & 82.79 & 100 \\
\hline 2010 & 10.86 & 89.14 & 100 \\
\hline
\end{tabular}

c. Note: This data is excerpted from Statistics and Census Service, Government of Macao Special administrative Region.

\section{THE PREDICTIONS ON LAND SUPPLY, POPULATION GROWTH AND INDUSTRIAL DEVELOPMENT FOR NEXT DECADE}

\section{A. The Obviously Hindered by the Shortage of Land}

"Fig. 1" shows the change of land area and land growth rate in the past. The column shows the change of land area. From 1992, the land area in Macao has been on an increasing trend. The total land area is constantly increasing. The land area nearly doubled to $29.7 \mathrm{~km} 2$ in 2010 . However, with a close look at the chart you will easily find that the slope of the columns is gradually decreasing. It means that the speed of land growth is gradually slowing down. It will even possibly stagnate in the future. The line segment in this chart stands for land growth rate. It rises in a wave mode. During the periods from 1992 to 1994 , from 1994 to 1997 and from 1997 to 1999 , it rises at the maximum amplitude, because there have been large scale sea reclamations during these three periods. However, the five wave amplitudes after 1999 gradually decrease. At this period of time, the sea reclamation has moved to the deep sea area and the cost of sea reclamation has increased, so the scale and growth rate of sea reclamation decreased significantly. With this trend, there will be increasingly smaller room for Macao to carry out sea reclamation, and finally there will be no room at all. On the one hand, this shows that sea reclamation will not meet the need of land for economic growth and industrial diversification for Macao in the future. And on the other hand, it shows that in Macao the contradiction between land supply and demand will become increasingly severe in the future. 


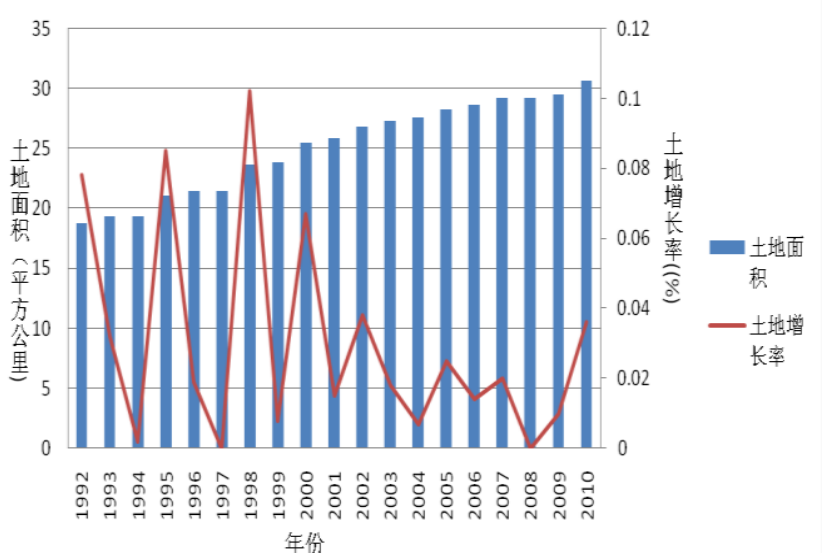

Fig. 1. The land stock and land growth from 1992 to 2010 in Macao

\section{B. An Earnest Want of Land in the Future}

In Macao, the stock of land and incremental of land are both limited, so the contradiction between land supply and demand will be intensified in the future. However, with the strong support from the central government and strong governance from the Macao SAR government, Macao has not only witnessed a leap-forward development in economic growth over one decade after its returning, but will also see a strong momentum in economic growth for a very long period of time in the future. This momentum comes from the result of opening of gaming industry and opening of traveling to the mainland China, and will lead to an earnest demand of land in the future. "Fig. 2" describes the growth of GDP from 1991 to 2010 . The sample data is the gross domestic product calculated with basic price by the production approach. From this chart, we could find that the economic aggregate in Macao is on a rising trend since 1991. It rises from 263.09 million Macao dollars in 1991 to 2262.63 million Macao dollars in 2010, which is 9 times as much as in 1991. On the view of the changing trend, the economic aggregate of Macao is not rising smoothly, but rising with the alternatives of the steep rise and consolidation. According to some experts' analysis and calculation, this rising trend will not easily decline in the short term, but sees a great potential in the long run. The continual growth of Macao's economy and economic diversification will need more lands as the support. Therefore, there is an earnest want of land in Macao.

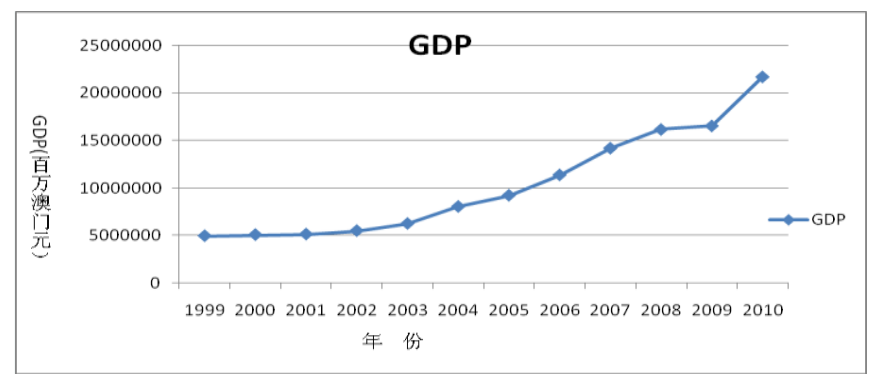

Fig. 2. The growth of GDP in Macao from 1991 to 2010

\section{Intensified Contradiction between Population Growth and Land Demand}

"Fig. 3" shows the increase of total population and population growth rate. The column stands for the total population. We could find from those columns that the total population is increasing steadily from 1992 to 2010. During those 18 years, the total population in Macao increases from 363,800 to 560,200 , an increase of about $52 \%$. If we connect the top of the column, we will then have a line which is nearly straight. This shows that the total population in Macao has an intrinsic motive and trend to increase. The segment line stands for the population growth rate. It shows that the population growth fluctuates and changes irregularly. According to this trend, the population in Macao still sees a great potentiality. Thus, the contradiction between population growth and land demand will be increasingly intensified in the future.

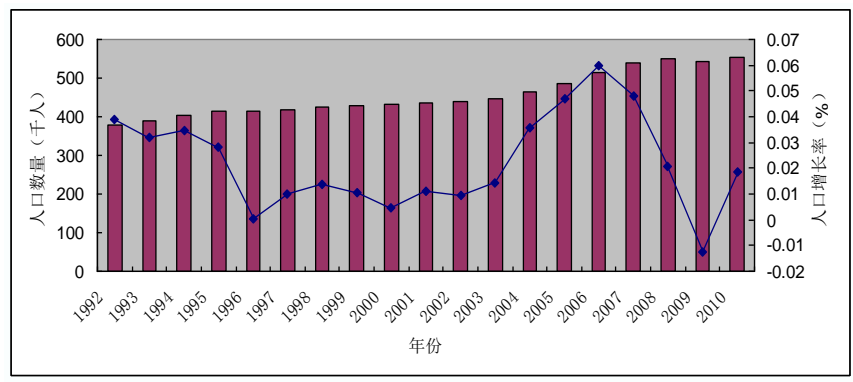

Fig. 3. The total population and population growth rate in Macao from 1992 to 2010

\section{The Evaluation and Prediction of Future Land Supply and Demand}

Let's assume that the economy and population in Macao will continue to grow in the future. Under this assumption, we could then predict the future situation of land, population growth and economic growth through the calculation and simulation of the historical data. In this way, we could then have a better evaluation of the land supply and demand in Macao. Taking the historical data from 1991 to 2010 as an example, we will make a regressive analysis of the relationship between land and population, land and industry, land and economic aggregate. We will get the following simulation, in which S stands for land scale, X1 for Macao's GDP, X2 for GDP of tertiary industry, and X3 for the total population:

$$
\begin{aligned}
& \log (\mathrm{S})=-9.64-1.31 \log (\mathrm{X} 1(-1))+0.77 \log (\mathrm{X} 2(-1))+ \\
& 3.10 \log (\mathrm{X} 3(-1)) \\
& \begin{array}{lll}
\mathrm{se}=(0.77) & (0.25) & (0.264) \\
\mathrm{t}=(-12.56) & (-5.14) & (2.901)
\end{array}
\end{aligned}
$$

The economy, gross industrial value and population have a delayed effect on the land, so this paper will apply the form of first order lag. Through calculation, all coefficients are under the confidence level $1 \%$ and the refuse coefficient is 0 . In addition, R2 has reached $97 \%$, which illustrates that this simulation has reached a good result. 
"Table IV" is the regressive result of GDP, GDP of tertiary industry, population and time. All coefficients are under the confidence level $0.05 \%$ and the refuse coefficient is 0 . This simulation has reached a good result. In the simulation above, $\mathrm{T}$ equals to $1,2, \ldots, 19$.

TABLE IV. The REgReSSION RESUlt OF LOG(X1), LoG(X2), LOG(X3) AND T (TIME)

\begin{tabular}{|c|c|c|c|}
\hline \multirow[t]{2}{*}{ Variable } & \multicolumn{3}{|c|}{ Coefficient } \\
\hline & $\log (X 1)$ & $\log (X 2)$ & $\log (X 3)$ \\
\hline $\mathrm{C}$ & 10.201 & 10.039 & 5.889 \\
\hline $\mathrm{T}$ & 0.066 & 0.066 & 0.021 \\
\hline
\end{tabular}

As mentioned above, under the assumption that the economy in Macao will continue to grow steadily, we take formula (1) and the equation of "Table IV" as analog, and the numerical simulation of land, population, GDP and GDP of Tertiary industry from 2010 to 2020 is calculated. From "Table V", we could find that in 2020 the population in Macao will reach 672,900, the GDP will reach 434.561 billion Macao dollars, and the GDP of tertiary industry will reach 389.801 billion Macao dollars. Therefore, the demand of land area in 2020 will be 43.38 square $\mathrm{km}$, which is 1.46 times as much as that in 2010. In other words, in order to meet the need of economic growth and economic diversification, the total land area must increase $54 \%$ by 2020, with an annual increasing rate of about $5.1 \%$.

TABLE V. The Prediction of Future LAND AREA, Population, GDP AND GDP of Tertiary Industry IN MACAO

\begin{tabular}{|l|l|l|l|l|}
\hline & Land Area & Number of Population & \multicolumn{1}{c|}{ GDP } & GDP of Tertiary Industry \\
\hline \multicolumn{1}{|c|}{ Year } & $($ Square $\mathbf{k m})$ & \multicolumn{1}{|c|}{$(\mathbf{1 0}$ thousand) } & $(\mathbf{1 0 0}$ million Macao dollars) & (100 million Macao dollars) \\
\hline 2010 & 29.70 & 56.01 & 2262.63 & 2013.75 \\
\hline 2011 & 30.15 & 56.85 & 2378.53 & 2116.89 \\
\hline 2012 & 31.51 & 57.26 & 2565.64 & 2281.65 \\
\hline 2013 & 32.63 & 58.22 & 2783.54 & 2477.35 \\
\hline 2014 & 33.78 & 59.64 & 2978.83 & 2654.14 \\
\hline 2015 & 35.96 & 61.33 & 3142.43 & 2806.19 \\
\hline 2016 & 37.01 & 62.28 & 3353.56 & 3003.65 \\
\hline 2017 & 39.25 & 63.61 & 3536.43 & 3168.65 \\
\hline 2018 & 40.82 & 65.18 & 3845.63 & 3449.53 \\
\hline 2019 & 42.05 & 66.38 & 4054.53 & 3636.92 \\
\hline 2020 & 43.38 & 67.29 & 4345.56 & 3898.01 \\
\hline
\end{tabular}

\section{AN EMPIRICAL ANALYSIS OF THE LAND CAPACITY}

\section{A. Index System for Population Carrying Capacity of Land}

The population carrying capacity of urban land means the threshold value of the economic scale and strength, which the land and population could support during a certain period of time, under a certain economic, ecological and social conditions, and within a certain space limit. As a micro economy, Macao has formed its own intensified population distribution pattern, population density and economic scale by its own land resources and ecological situation. Therefore, referring to Professor YU Danlin and several other scholars' research methods, this paper endeavors to construct an index system for population carrying capacity of land in Macao as showed in "Table VI".

TABLE VI. AN INDEX SySTEM FOR POPUlATION CARRYING CAPACITY OF LAND IN MACAO

\begin{tabular}{|c|c|c|c|c|}
\hline Target layer A & Criteria layer B & Criteria layer C & Index layer D & Unit of Measurement \\
\hline \multirow{18}{*}{$\begin{array}{l}\text { Comprehensive } \\
\text { carrying capacity } \\
\text { of land in Macao }\end{array}$} & \multirow{10}{*}{$\begin{array}{l}\text { The index of } \\
\text { Pressure }\end{array}$} & \multirow{4}{*}{$\begin{array}{l}\text { Pressure from Social } \\
\text { and economic } \\
\text { development }\end{array}$} & GDP per capita & Ten thousand Macao dollars per person \\
\hline & & & GDP per capita of tertiary industry & Ten thousand Macao dollars per person \\
\hline & & & Gross social capital formation per capita & Macao dollars per person \\
\hline & & & Gross income of local residents per capita & Macao dollars per person \\
\hline & & Population Pressure & Population density & Thousand people per square $\mathrm{km}$ \\
\hline & & \multirow[t]{3}{*}{ Resource consumption } & Water consumption per capita & Ton per person \\
\hline & & & Consumption of electric energy per capita & Kwh per person \\
\hline & & & Energy consumption per capita & MJ per person \\
\hline & & \multirow{2}{*}{$\begin{array}{l}\text { Environmental } \\
\text { pressure }\end{array}$} & Amount of MSW clean-up per unit of land & Ton per square $\mathrm{km}$ \\
\hline & & & Sewage letting quantity per unit of land & Ton per square $\mathrm{km}$ \\
\hline & \multirow{6}{*}{$\begin{array}{l}\text { The index of bearing } \\
\text { pressure }\end{array}$} & \multirow[t]{3}{*}{ Urban Planning } & Urban green land ratio & $\%$ \\
\hline & & & urban road area ratio & $\%$ \\
\hline & & & urban construction land ratio & $\%$ \\
\hline & & \multirow{2}{*}{$\begin{array}{l}\text { Environment } \\
\text { Procession }\end{array}$} & Solid waste treatment ratio & $\%$ \\
\hline & & & Waste water treatment ratio & $\%$ \\
\hline & & Educational level & $\begin{array}{l}\text { The proportion of graduates of higher } \\
\text { education }\end{array}$ & $\%$ \\
\hline & \multirow{2}{*}{$\begin{array}{l}\text { The index of } \\
\text { exchange }\end{array}$} & & Foreign Trade Dependence Degree & $\%$ \\
\hline & & & The proportion of FDI in GDP & $\%$ \\
\hline
\end{tabular}

d. Note: This index system of population carrying capacity of land in Macao is constructed with reference to YU Danlin's study (YU Danlin, 2003) on the research method of index system of regional disaster. 


\section{B. Methodology and Econometric Model}

- This paper will select $\mathrm{n}$ indexes which can well describe the comprehensive population carrying capacity of land and then calculate its present value, marked as $\mathrm{RCSi},(\mathrm{i}=1,2, \ldots \ldots, \mathrm{n})$.

- Allowing for sustainable development principle and the land utilization in Macao, this paper will select $\mathrm{RCCi}$, the ideal value of those $\mathrm{n}$ indexes. Limited to the statistic scope and data searching channel, however, this paper will choose the city of Shenzhen, where there is a great comparability with Macao in terms of land, population and economic growth, as the ideal value and reference for Macao's population carrying capacity of land. Therefore, all ideal values mentioned in this paper are excerpted from the city of Shenzhen.

- Allowing for the specific region, this paper will then reorder those $\mathrm{n}$ indexes in sequence of importance, and calculate the weight of each index, marked as wi $(\mathrm{i}=1,2, \ldots \ldots, \mathrm{n})$. We will apply the variance method to calculate the weight. The detailed steps will be shown below and the weight of each index will be shown in "Table VII".

- We will construct an n-dimensional state space with those $\mathrm{n}$ indexes. The vectors of ideal value RCCi and n-dimensional state space will stand for the state point of land carrying capacity under the present situation of economics and population. Their positions in the state space reflect the population carrying capacity of land in Macao. In order to simplify the analysis of carrying capacity, this paper will adopt the following steps:

Construct the vector $\left(\mathrm{RCSi}^{*}\right)$, for the restricted indexes:

$$
\mathrm{RCSi}^{*}=\mathrm{RCSi} / \mathrm{RCCi}
$$

While for the development indexes:

$$
\mathrm{RCSi}^{*}=\mathrm{RCCi} / \mathrm{RCSi}
$$

Its effect lies in that every element of the vector ( $\mathrm{RCSi}^{*}$ ) can be described as the ideal land carrying capacity within a duration when the value of $\mathrm{RCSi}^{*}$ is either $>1$ or $=1$ or $<1$. This ideal land carrying capacity will be the reference, which indicates in a respect the state of population carrying capacity of land. In addition, weighted distance $M$ between n-dimensional state space and origin of coordinate is the actual population carrying capacity of land in Macao:

$$
M=\sqrt{\sum_{i=1}^{n}\left(w_{i} \cdot R C S^{*}\right)^{2}}
$$

Through the processing of equation conversion, the state vector $\mathrm{RCCi}^{*}$, which stands for the comprehensive population carrying capacity of land in Macao, actually transforms to be a unit vector. Through the weighting process, empirical econometric model of this unit vector will be:

$$
R C C=\sqrt{\sum_{i=1}^{n}\left(w_{i} \cdot R C C_{i}^{*}\right)^{2}}=\sqrt{\sum_{i=1}^{n} w_{i}^{2}}
$$

According to the comparison between $\mathrm{M}$ and $\mathrm{RCC}$, we can make a preliminary value judgment of the actual carrying capacity of land in Macao:

$$
\begin{aligned}
& \text { M > RCC over-loaded } \\
& \mathrm{M}=\mathrm{RCC} \text { full-loaded } \\
& \mathrm{M}<\mathrm{RCC} \text { still-loadable }
\end{aligned}
$$

\section{Empirical Analysis of Land Capacity}

1) Data source: The data selected in this paper are all from the website of Macao Statistics and Census Service, website of Macao Cartography and Cadastre Bureau, "Shenzhen Statistical Yearbook 2010" and "China City Statistical Yearbook 2010". The value index in this paper takes 2009 as the base period. Based on standardization, all indexes will be processed according to the steps mentioned above.

2) Variance Method: The variance method will be applied in this paper. From 2.2, we could get a dimensionless decision matrix of Macao's land carrying capacity. This matrix will be marked as $Z=\left(Z_{i j}\right)_{n \times m}$, the specific steps will be as below:

According to the equation of $E\left(G_{j}\right)=\frac{1}{n} \sum_{i=1}^{n} Z_{i j}$, we could calculate the mean value $E\left(G_{j}\right)$ of the random variable;

Through the equation of $\sigma\left(G_{j}\right)=\sqrt{\sum_{i=1}^{n}\left[Z_{i j}-E\left(G_{j}\right)\right]^{2}}$, we will then calculate the mean square deviation of the index set $G$;

3) The realistic evaluation of population carrying capacity of Macao's urban land:

Combining with the results mentioned above, we could then calculate the weighting coefficient $W_{j}$ : $W_{j}=\sigma\left(G_{j}\right) / \sum_{i=1}^{m} \sigma\left(G_{j}\right)$ of the index set G. The calculation result is shown in "Table VII". 
TABLE VII. THE Weight of ALl INDEXES FOR MACAO’s POPUlation CARRYING CAPACITY OF LAND AND THE RCSI*(STATE VECTOR OF CARRYING CAPACITY) IN 2009

\begin{tabular}{|c|c|c|c|}
\hline & The Index layer & RCSi* & Weight \\
\hline \multirow{18}{*}{$\begin{array}{l}\text { The population } \\
\text { carrying capacity } \\
\text { of land in Macao }\end{array}$} & GDP per capita & 2.828 & 0.0579 \\
\hline & GDP per capita of tertiary industry & 4.724 & 0.0549 \\
\hline & Gross social capital formation per capita & 0.025 & 0.0565 \\
\hline & Gross income of local residents per capita & 7.202 & 0.0532 \\
\hline & Population density & 4.107 & 0.0579 \\
\hline & Water consumption per capita & 1.601 & 0.0603 \\
\hline & Consumption of electric energy per capita & 0.983 & 0.0605 \\
\hline & Energy consumption per capita & 0.263 & 0.0565 \\
\hline & Amount of MSW clean-up per unit of land & 2.265 & 0.0511 \\
\hline & Sewage letting quantity per unit of land & 3.897 & 0.0489 \\
\hline & Urban green land ratio & 1.878 & 0.0532 \\
\hline & urban road area ratio & 0.322 & 0.0608 \\
\hline & urban construction land ratio & 1.494 & 0.055 \\
\hline & Solid waste treatment ratio & 1.565 & 0.0516 \\
\hline & Waste water treatment ratio & 0.93 & 0.0524 \\
\hline & The proportion of graduates of higher education & 0.202 & 0.0509 \\
\hline & Foreign Trade Dependence Degree & 8.55 & 0.0548 \\
\hline & The proportion of FDI in GDP & 3.769 & 0.0635 \\
\hline
\end{tabular}

"Table VII" is the weights of every indexes and Macao's $\mathrm{RCSi}^{*}$ in 2009 according to the empirical steps mentioned above. Then we substitute it into the formula (4) and (5), the following could be get:

$$
\begin{aligned}
& M=\sqrt{\sum_{i=1}^{n}\left(w_{i} \cdot R C S_{i}^{*}\right)^{2}}=0.814 \\
& R C C=\sqrt{\sum_{i=1}^{n}\left(w_{i} \cdot R C C_{i}^{*}\right)^{2}}=\sqrt{\sum_{i=1}^{n} w_{i}^{2}}=0.23
\end{aligned}
$$

The calculation shows that $\mathrm{M}>\mathrm{RCC}$ and $\mathrm{M}$ is more than two times of RCC2. Taking the city of Shenzhen as the reference, the land area in Macao is only $14.8 \%$ of that in Shenzhen, while Macao carries 3 times more of population, economy and environmental ecology than that in Shenzhen. Therefore, we could conclude that the carrying capacity in Macao is obviously in an overloaded state.

4) The Trend Analysis of the Development of Population Carrying Capacity of Land in Macao: In order to seek a comparability of the related data in a certain time sequence, the standard value of Macao's population carrying capacity of land is all selected from the Shenzhen's indexes in 2009. According to the steps above, we could get the trend of Macao's population carrying capacity of land from 2003 to 2009, which will be shown in "Table VIII".

TABLE VIII. The DEVElopMent TREND of MACAO’s POPUlATION CARRYING CAPACITY OF LAND FROM 2004 TO 2009

\begin{tabular}{|c|l|l|l|l|l|l|l|}
\hline Year & 2003 & 2004 & 2005 & 2006 & 2007 & 2008 & 2009 \\
\hline $\begin{array}{c}\text { The comprehensive land carrying } \\
\text { capacity in Macao (Mi) }\end{array}$ & 0.5026 & 0.5588 & 0.6037 & 0.6405 & 0.7385 & 0.7387 & 0.8143 \\
\hline
\end{tabular}

With the data from "Table VIII", we could simulate the development trend of Macao's population carrying capacity of land. As shown in "Fig. 4", the population carrying capacity of land in Macao has nearly a straight-line diagonally upward trend. This shows that the pressure of Macao's population carrying capacity is increasing. There will be an increasingly larger demand for land space, and a stricter requirement of both population carrying efficiency and carrying capacity of land in Macao.

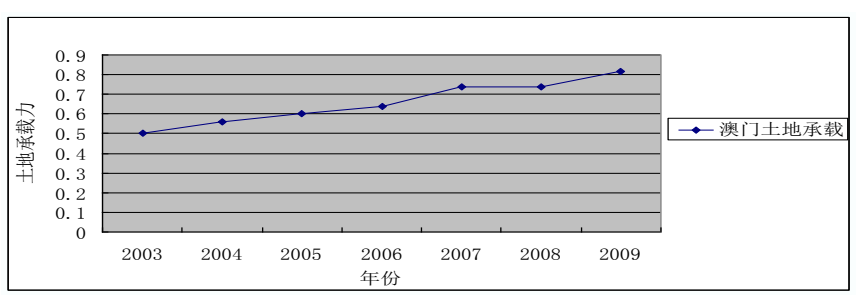

Fig. 4. The simulation of population carrying capacity of urban land in Macao

\section{CONCLUSION}

During those ten years after Macao's returning, it has witnessed a rapid economic growth. However, the population carrying pressure of land has increased greatly due to the small land area and high population density. Thanks to the great support from the central government, the compulsory governing from the SAR government and the joined efforts from all walks of life in Macao, Macao's economy has made a leap-forward development during this one decade. From 1999 to 2012, the average annual economic growth rate of Macao is as high as about $13.5 \%$. In 2012, its per capita GDP is about 50, 000 dollars, surpassing Japan, Hong Kong, Singapore and Taiwan. It has become one of the highest per capita GDP areas in the Asia-pacific region. Though Macao has the highest economic growth rate and the most developed economy, it is also an ultra-micro economy with a very small land area and most densely population. Macao has a land area of only 29.5 square $\mathrm{km}$, which carries a large population of 550,000 and a huge economic aggregate of 
nearly 169.34 billion Macao dollars. Even compared with Shenzhen, the city which has the most rapid economic and population growth in Mainland China, Macao's land area is $1 / 67$ of that in Shenzhen and its population $1 / 20$, but the GDP carried by every square km of land area in Macao is 12 times of that in Shenzhen and the population is 42 times. The small land area, the severe land contradiction between land supply and demand, and the high pressure of land carrying capacity has become the key factors restricting Macao's economic diversification in the new era.

For the next decade, Macao still has a strong momentum of economic and population growth, but the contradiction of land supply and demand for economic and population growth will become increasingly severe. Sea reclamation has been the major way to expand land resources for a long period of time. However, sea reclamation has reached the deep sea area, so the cost has risen too much and the land resources being able to be further reclaimed are now very limited. According to the relevant calculation and analysis, Macao's economy, leading by gaming industry, will still develop very fast in the next decade. The population will still increase with the inertia of economic development. To meet with the economic development and population growth, the incremental demand for land will be as much as $5.2 \%$. By 2020 , the population will reach as much as 67,800 , and the GDP will be 200 billion Macao dollars. Meanwhile, the total land demand will be 46.4 square $\mathrm{km}$. However, there is a land stock of only 29.5 square $\mathrm{km}$ at present. Furthermore, there lacks for future land expanding measures.

Through empirical analysis and calculation, the urban land and population carrying capacity in Macao has been seriously overloaded. Furthermore, this overloaded state will be increasingly intensified in the future. We first construct an index system of land and population carrying capacity in Macao. With the application of econometric model and empirical analysis, we then evaluate and calculate the land and population carrying capacity. Taking the city of Shenzhen as a reference, our calculation shows that M>RCC and $\mathrm{M}$ is more than two times of RCC. The land area of Macao is $14.8 \%$ of that of Shenzhen, but compared with Shenzhen, every square $\mathrm{km}$ of land in Macao carries more than three times of economy and population. The present land and population carrying capacity has been obviously and seriously overloaded. What's more, according to the simulation, the population carrying capacity of land in Macao will bear an increasingly higher pressure and the contradiction between land supply and demand will become more severe and prominent in the future.

The best way to solve the problem of Macao's population carrying pressure of land is to reform the land system, optimize the land use structure and improve the land carrying efficiency. Like Macao, Singapore is also a highly-developed micro economy with a large population but a small land area. However, thanks to the scientific land planning and management, orderly layout of production and residential land, and high intensified economy, the incremental land storage for future economic development and population growth is quite sufficient. With an outdated land system and disordered land planning, the land use structure is imbalanced. In Macao, the production land and residential land are too scattered and the gambling land is interspersed with residential land. Thus, the contradiction between land supply and demand becomes even more severe. It would be necessary for Macao to learn from Singapore in terms of land system reform and long-term planning of land and population. Macao could improve the population carrying capacity of land and population carrying efficiency of land through the optimization of industrial layout and land use structure. Singapore's successful experience tells us that a small city could greatly improve the land carrying efficiency to hold more economic and social activities through exquisite and orderly land planning.

The fundamental way to expand Macao's land area is to conduct land lease and land replacement through the regional cooperation among Hong Kong, Macao and Pearl River Delta. Now that the room for sea reclamation is decreasing and the contradiction between land supply and demand for economic development and population growth is intensified, the fundamental way to expand the land area is to conduct land lease and land replacement in market economy through the regional cooperation among Hong Kong, Macao and Pearl River Delta. In this way, there would be enough land to meet with the economic development and population inertia growth. "The overall planning of Hengqin", which is approved and promulgated by the State Council, states clearly that the development of Hengqin should provide the necessary land for the economic diversification of Macao. The founding of Hengqin New Campus of University of Macau is a realistic example to solve the contradiction between land supply and demand through regional cooperation among Hong Kong, Macao and Pearl River Delta. Therefore, Macao should take the development of Hengqin as an opportunity to extend the industrial chain and expand the industrial land. Taking the regional cooperation among Hong Kong, Macao and Pearl River Delta as the platform, Macao could apply the land lease, land replacement and joint venture and investment as the main means to realize Macao-Zhuhai industrial junction and urban integration.

\section{REFERENCES}

[1] Chen Guanghan "Macao economic and appropriate development of the face of the difficulties and policy choices", Hong Kong and Macao Economic Yearbook 2010, Beijing: Hong Kong and Macao Economic Yearbook, 2010: 345th - 352.

[2] Li Houqiang, Chen Zhangxi, He Wenhui, Qu Chu Dong: Macao land development and urban space development empirical research. Macao research, 2010, (3): 68-73.

[3] Guo Hengliang, Zhao Dongping: "sustainable development of Macao twenty-first Century", Shaanxi Institute of technology, 2001, (3): 5156.

[4] Huang Hanqiang, Wu Zhiliang: "Macao Overview", Beijing: Chinese Friendship Publishing Company, 1999.

[5] Wei Suqiong, Lan Dingding, Chen Zhiqiang: a preliminary study on the bearing capacity of urban land resources -- Taking Fuzhou as an example, Journal of Shenyang Normal University (NATURAL SCIENCE EDITION), 2007, (2): 256 - 252.

[6] Tan Zongbo,Dong Ke, "Macao land use and planning system research", urban planning, 1999, (12): 30 - 36. 
[7] Tang Kaijian: today Macao, Beijing: Higher Education Press, 1999: $16-15$.

[8] Wang Mingtao: "the decision of the right effect in the comprehensive evaluation of multiple indicators", economic geography, (4): 272 277.

[9] Xu Jianhua: "mathematical methods in modern geography", Beijing: Higher Education Press, 1994.

[10] Yang Jun: "Macao environmental geological changes to the tourism environment impact study", Shaanxi: Chang'an University, 2009.

[11] Yang Yue: "Macao land resources scarcity and real estate development", the Chinese market, 1998 (5): 52 - 53.

[12] Yu Danlin, Mao Hanying, Gao group: "the state space measures the regional bearing capacity of the case study of the Bohai region," the study of geography, 2003, (2): $210-201$.

[13] Zheng Tianxiang, Huang Shun: "Macao's urban form and urban planning", economic geography, 2006 (4): 277 - 272.

[14] Lin Guangzhi, et al. Macao economic and social development report, Beijing: Social Science Literature Press, 2012. 